\title{
Does Compensation \& Benefits Matters to Working Women to Perform Well? A Case of Public School
} Teachers

\author{
Amir Saif, Maira Amir, Fawad Hussain \\ Department of Business Management, National College of Business and Economics (NCBA\&E) \\ Multan, Pakistan \\ amirsaif9001@gmail.com, amir.saif@masgroup.org
}

\begin{abstract}
Pakistan is a developing country and with the changing global trend, technological advancement and human development are taking place. As we know that training and development is a constant growing process which keeps improving the excellence of employees. In education sector training, development and continuous learning play an important role. Teachers spend their lives grooming our children, youth and shaping our generations. Education is the key element for the success of any society. But unfortunately, there are various reasons why the quality of learning and competency level in the Public sector is not up to the benchmark both for students and teachers in Pakistan. According to report 2015-16 of Pakistan education institution of statistics the total primary schools is 145829 of 145 , in which is 125573 is public primary school. On the other hand, as per education statistics there are a total of 422,797 primary school teachers of which $324,561(77 \%)$ represents the public sector With such a huge contribution of public schools, there is a great room of improvement for teacher particularly their educational capability to deliver, then only a gradual change can be seen in the long run. The aim of the study is investigating the relationship between training and development, work engagement and women public teachers' performance. This study also examines compensation \& benefits as a moderating variable. This study has used a total of 220 samples to analyze the data. The study has used Smart PLS and SPSS 22 statistical technique to analyze the data. This study used a quantitative method, in which data collected from working women (public school teachers) in Multan, Lodhran, Khanewal, and Vehari cities of the province Punjab in Pakistan. The findings have concluded that there is a significant relationship between training \& development, work engagement and employee performance. However, compensation \& benefits do not found to be a moderating variable. This research will be helpful for women public teacher's related issue to training, work engagement, compensation, and benefits. The study recommends this problem could be resolved by considering some basic measures such as appropriate government policy for public teachers training and development, foolproof accountability system, education quality assessment. Injecting latest talent in the education system, international competitive pay scale, and merit-based transparent hiring process and believe that only education can change our children's future.
\end{abstract}

Keywords: Work Engagement, Training and Development, Employees Performance.

\section{Introduction}

Human asset Training and Development is essential in accomplishing the objective of the association as it expands the productivity and adequacy of workers and advertisements esteem in the hierarchical accomplishment (Abdullah, 2009). This research is significant for the quality of teaching teachers required to be improved in a manner to encourage the standard of education in the Punjab province of Pakistan. There is inattention of administrative bodies to look at the teachers training \& development, their work engagement and teacher's compensation and benefits could possibly essential factors for improving teachers' performance. However, achieving this objective will be definitely required a higher quality of educational machinery including teachers and administrative body which identify the weaknesses, evaluate the current senior, monitor, control and developing work performance of public teachers in Pakistan. This research paper is adding-value to knowledge in term of human resources at public educational institutes which plays a vital role in achieving the performance-based goals.

Public Education Overview in Pakistan: According to Pakistan Education Statistics (2015-2016) the education system of Pakistan is encompassed of 303,446 institutions and is assisting 47,491,260students with the help of 1,723,790 teachers. The system is composed of 191,065 public institutions and 112,381 private institutions. In Pakistan, the public sector is serving 27.69 million students to complete their education. 
Primary Schools: According to Pakistan Education Statistics (2015-2016) there are a total of 145,829 primary schools, out of these 125,573 (86\%) are in the public sector, whereas,20,256 (14\%) are in the private sector. Comparatively, from 2011 to 2016 (five years), a decline of about $10 \%$ was observed.

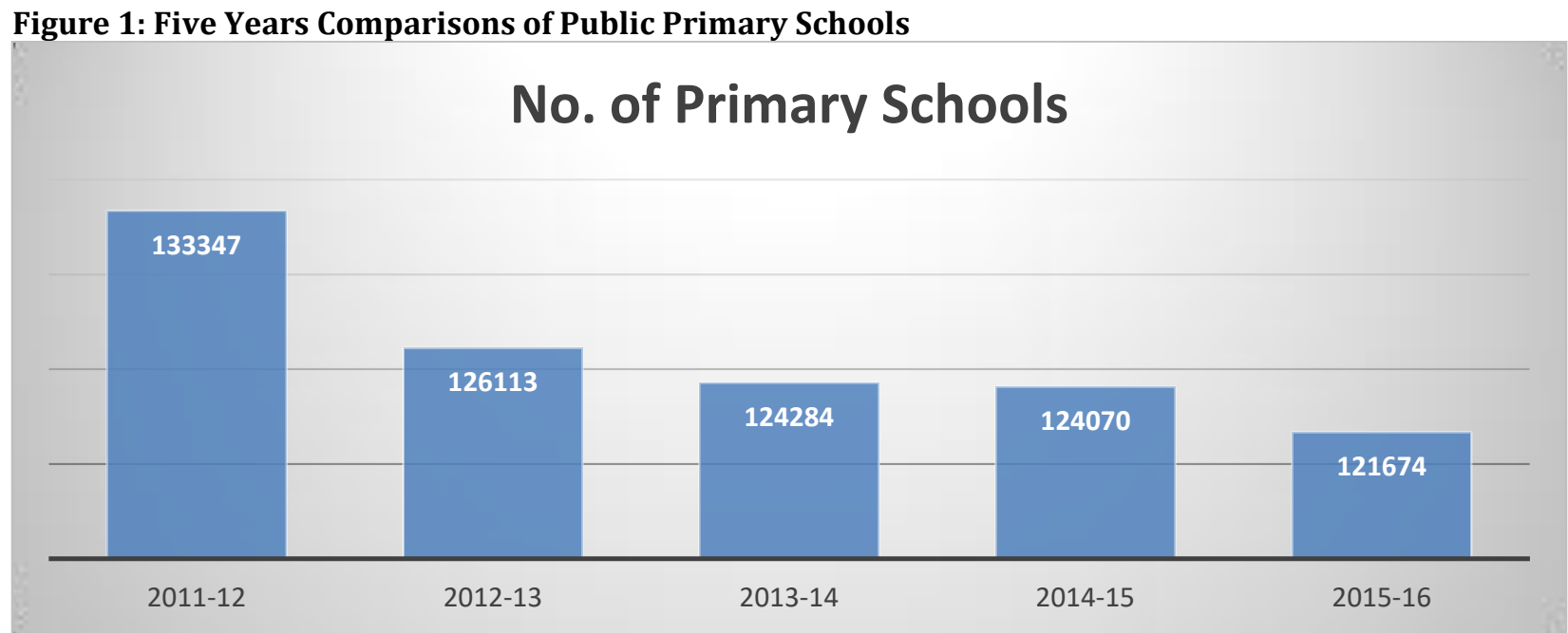

Source: Pakistan Education Statistics (2015-2016)

There are a number of reasons why these schools are decreasing. Firstly due to the closing of non-functional schools, as per the rationalization policy, secondly the upgrade of these public primary schools to higher levels. Thirdly due to the merger of schools, due to limited teachers or lack of student enrolment, the government has also taken serious steps against those schools which are on the record but not function and its employees are taking their salaries and benefits on a regular basis, which seems unjustifiable. However, despite a decrease in the number of primary schools, an increase in enrolment is recorded.

Primary Schools Teachers: The total numbers of a primary school teacher are 4229799 of which 324561 are the govt sector, whereas 98,236 are in the private sector

Problem Statement: In Pakistan, even the major changes are taking place but still, the public education sector is considered to under develop and requires the attention of the government. There is a scattered and demotivated feeling between the teaching societies. The reason because teaching professional is considering the mainly less profitable, poorly paid insecure and unappealing profession (British Council, 1988; Farooq \& Kai, 2017). Pakistan is one in which eight (8th) countries internationally that spend less two percent (2\%) of GDP in education. Public disbursements on education, a vital input for development in more and high quality, are a mere $1.5 \%$ of GDP. Female literateness is $45 \%$ beside male literateness rate of $69 \%$. On average $32 \%$, $40.5 \%$ and $67.7 \%$ of country girls old 5-10, 10-14 and 15-19 consistently are out of school. Less than half of students are infrequently comprehensive primary school. The excellence of education in the government school has failed substantially. Today, around 25 million children in Pakistan not reach to their statutory right to have education up to the age of 16 . Average knowledge rate is only $57 \%$ in the country.

Derisory admittance to the schools, low attendance and poorly trained teachers as well as weak supervision creates this pity situation (Farooq \& Kai, 2017). Like other sensitive departments such as Police, central board of revenue (CBR), Electric, Gas, education is also facing typical problem of compensations and benefits, which ultimate a big question mark from education policy maker that "Can a primary school teacher (PST) survive in PKR 10,242 (U\$D : 73.37) per month?" What he will teach? And what quality he will provide to the students? And what will be his qualification? And For how long he will be committed to the school? Previously there are various researchers (Hashami, 2016) who have pointed out that the condition of the primary school is quite disgusting, so the student has no interest to go to the school and it was also noted that there is a high ratio of absenteeism among the primary school teachers. To answer this question, this study is aiming to investigate the given below research objective. 
Research Objective: Following are the research objectives of this research:

- To investigate the relationship between training \& development and public schools teacher performance.

- To investigate the relationship between work engagement and public schools teacher's performance.

- To investigate the moderating role of teacher's compensation and benefits between training \& development, work engagement and public schools teacher's performance.

Research Question: Following are the research question of this research:

- What is the relation between training \& development and public schools teacher performance?

- What is the relation between work engagement and employee performance?

- What are the consequences of compensation and benefits which probably could moderate between training \& development, work engagement and public schools teachers' performance?

\section{Literature Review}

Employee Performance: Employee performance is usually observed at in relations of productivity or results. These results could be in term of production performance or service enactment. Kenney (1992) stated that the employee's performance is evaluated against the performance standards set by the firms. However, firms measure the performance of employees in various ways such as employee efficiency, productivity, effectiveness, profitability and quality aspects (Nassazi, 2013). Furthermore, Anitha, (2014), noted that employee performance is typically in an outcomes accomplishments and achieved prepared at work. She added that performance denotes to keeping up the plan while aim for the relevant results. Similarly, Diamantidis \& Chatzoglou, (2019) investigate the interrelation between company related factors (as such training culture, management support, environmental factor and organization changes climate), factor related to job (job environment, job autonomy, community job) and factor employee related (fundamental motivation, skill tractability, level of skills, proactivity, flexibility, and commitment) and their impact on employee performance.

The study found that job environment and management support have the strongest influences (indirect and direct) on job performance, while flexibility and intrinsic inspiration straight effect on job performance. In addition, Shem and Ngussa, (2015), conducted a study on 149 teaching and non-teaching staff in Institutes of Higher Learning in Arusha City-Tanzania, found that off-job training, on-job training, and mentoring / coaching, are positively associated with job performance, which indicated that teacher's training is a good predictor of student's learning. While teachers constantly enhance staff skills through regular training in terms of seminars, workshops, and related aspects whilst providing them with important resources for effective performance (Naris \& Ukpere, 2012). In this study, we have utilized various employee based attributes in explaining employee performance. These attributes are training and development work engagement, compensation \& benefits and employee performance. On a similar note, Nabi, Syduzzaman, and Munir, (2016) conducted research on job training and employee performance, found that employee job performances were significantly influenced by job satisfaction. However, it was evidenced that job training is a significant influence on job satisfaction of employee.

Moreover, there the authors Nassazi, (2013) conduct the research on examining the effect of training on employee performance in Uganda telecommunication industry found that employee contribution in the training and recruitment for training show that telecommunication enterprises in Uganda have worthy and clear policies about employee training as maximum number of the respondents indicated that they have participated in training which was quite useful and help them to improve their daily telecommunication service performance. On the other hand, there are some other factors like employee work engagement which are useful in explaining employee performance. The researcher such as Anitha, (2014) found employee engagement was a significant predictor of employee performance. In addition, this research will be using employee compensation \& benefits, which the previous researcher such as Feraro-Banta and Shaikh, (2017) found that there is an important association between employees' compensation and benefits and employee performance in audit firms in Bahrain. Moreover, previous research has also shown that employee 
recognition and employee performance are correlated. Shariful et al. (2013) found that critical recognition factor has a significant influence on employee performance.

Training and Development: Training and development remained the most prominent factor which has never lost its importance. As a Human Resource (HR) department has a backbone position in any organization. According to Van (1962) 'training is the process information or educated people, so they have become as well as qualify as a possibility to do their job. Qualified person to be performed is the well position of high difficulty and duty. The authors mentioned that their initial examination has found that due to the underperformance of human capital service industry sector is not getting a suitable push. Empirically the authors have found that human resources be able to contribute to the business substantially by being recognized in the organization. Moreover, Sabir et al. (2014) find the effects of training and development on the employee efficiency and effectivity by using the research technique, so find the significant relationship, In addition, Franklin et al. (2014) the researcher was used the quantitative research approach. The actual effects of research on electricity supply company find the effect of training on employee performance by using research techniques Sultana et al. (2012) consecutively define the effects of T\&D on employees' performance at Telecommunication sector in Pakistan by using methodology technique. Their study is well-known that there was a strong, optimistic link of training on employee performance and it increases the level of individual and organizational proficiency.

Hypothesis 1: There is a significant relationship between training \& development and employee performance.

Work Engagement: Employee work engagement is defined that the unit to which employee feels that they are involved, gratified with and expressively associated, to develop efficiency, modernization and retention (Abraham, 2012). Deepa et al. (2014) explained that worker's engagement in their specific work attributes as their valuing, participating with enjoyment, and priding of their work, accordingly they start putting more efforts on their jobs. Moreover they will start willing to do more and share useful information with other colleagues / subordinates to support each other, and likewise, the entire organization will perform well. Similarly, Saks, (2019), found that ability diversity is the foremost job characteristic that predicts job engagement.

Hypothesis 2: There is a significant relationship between work engagement and employee performance.

Compensation and Benefits: Employee compensation and benefits are directly moderate employees working motivation and dedication, which further leads to their satisfaction and performance. There are many factors that can moderate to employee performance, together with other factors this study will also ponder on public schools teacher's compensations and benefits. As long as all staff with compensations and benefits for undertaking their job well, most employees expect a level of admiration and recognition from their employers (Cunningham \& Mahoney, 2004). Regrettably, in the context of firms most part /full-time employee do not receive much compensation and benefits apart from stipulated agreement based on an annual or semiannual basis (Cunningham \& Mahoney, 2004). Moreover, Moncarz, Zhao, and Kay (2009) investigated how compensation and benefits influence employee performance job. Commonly employee compensation and benefits are a target for full-time employees only and ignoring the contractual employees or part-time employees. This makes the contractual or part-time employees suffer from availing any compensation or benefits.

But the previous researchers (Feraro-Banta \& Shirin, 2017) pointed out those employees' benefits and compensation in the audit firms in Bahrain could significant moderate performance of the employee. On the other hand, Moncarz et al. (2009) noted that allocating adequate compensation, incentives and benefitting approach of firms towards employees helped them to improve overall employee motivation leading to their better performance. In addition, Moncarz et al. (2009) recognized that advancements, customer centeredness, employee recognition, and rewards could boost the performance of an employee. Accordingly the employee will increase their self-confidence in their job environment and likewise, the employee will synergize themselves to the firm vision and performance-oriented goals. In addition, Feraro-Banta and Shirin, (2017) conducted research on hundred employees of the audit-based firm in the Kingdom of Bahrain found 
that there is an important relationship between employees' compensation and benefits and performance of employees.

The author further added that there were few problems which were encountered regarding compensation, and benefits, such as double standards for fair allocation of compensations and benefits and compensation against productivity and lack of transparency in terms of incentives. However, Copeley (2015) also demonstrates the positive impact of compensation policies on the company's overall performance. Similarly, Zack et al. (2009) found that compensation and benefits are critical element form employee attraction and retention tools to make them perform better.

Hypothesis 3a: There is a moderating effect of compensation \& benefits between training \& development and employee performance.

Hypothesis 3b: There is a moderating effect of compensation \& benefits between work engagements and employee performance.

\section{Methodology}

The study used method of descriptive research, in which existing status of women teachers at primary level in Multan Division (Multan, Lodran, Kanewal, Vehari) in the province of Punjab - Pakistan was thoroughly analyzed. The reason why only these four cities were considered to be included in the Survey is that these cities are hugely populated in Southern Punjab. In the mean, while schools and governance remained ignored since last few decades and core attention of local governance have focused other central cities in term of education, health, transport and environment. However, the quantitative research technique was used in this research and the data was collected through questionnaires. According to (Shem \& Ngussa, 2015; McMillan and Schumacher (2006), questionnaire possess scaled items followed by possible responses whereby respondents check the items on the scale that best reflect their beliefs or onions about the items. The questionnaire contained a list of items which were provided for respondents to express their views.

Each item in the questionnaire contained 5-point scale options from which respondents were to choose. Women problem of the school teachers were identified by using the quantitative research methods like as questionnaire or survey. The aim of sample size is to a suitable number of respondents to participate in the research. In this study, the population size includes 4000 female public school teachers in Multan Division. The measurement model and structural model were verified using Smart PLS logarithms. The study targeted sample size of 320 responses. Out of the 340 distributed questionnaires, only 220 were filled and returned. The statistically significant response rate for analysis should be at least $50 \%$ therefore in this research it was noted that the response rate was $68.75 \%$ as shown in Table 1 . The response rate conformed to this conclusion.

Table 1: Response Rate

\begin{tabular}{ll}
\hline Items & Response \\
\hline Questionnaire Distributed & 340 \\
Missing Field (Questionnaire More than 50\% Not Filled) & -50 \\
Non-Seriously Filled (Marked all SD or SA) & -40 \\
Unemployed / Students & -30 \\
Total Response & 220 \\
Response Rate Percentage & $68.75 \%$ \\
\hline
\end{tabular}

Loading: Testing the reliability and validity is very crucial in any study, therefore, all the factor loading values below 0.5 was deleted and shown in table 1 . It was suggested by Hair et al. (2006), that items loading value below 0.5 should be dropped in a directive to increase average variance extracted (AVE) index. Following to their suggestion, the researcher dropped the following items; CB11 (0.499312); TD3 (0.499285); TD4 (0.419422); TD5 (0.38472); TD6 (0.355994); WE11 (0.525634) and WE2 (0.462791). The factor loadings after items deleted can be Table 2 below. 


\section{Results and Discussion}

Table 2: Summary of Measurement Model

\begin{tabular}{|c|c|c|c|c|c|c|c|}
\hline Variables & Items & $\begin{array}{l}\text { Actual } \\
\text { Loadings }\end{array}$ & $\begin{array}{l}\text { Deleted } \\
\text { Loadings }\end{array}$ & AVE & $\begin{array}{l}\text { Composite } \\
\text { Reliability }\end{array}$ & R Square & $\begin{array}{l}\text { Cronbach's } \\
\text { Alpha }\end{array}$ \\
\hline \multirow{11}{*}{$\begin{array}{l}\text { Compensatio } \\
\text { n and } \\
\text { Benefits }\end{array}$} & CB1 & 0.605387 & 0.605628 & 0.40541 & 0.8716 & & 0.836886 \\
\hline & CB10 & 0.596777 & 0.546669 & & & & \\
\hline & CB11 & 0.499312 & Item Deleted & & & & \\
\hline & CB2 & 0.573373 & 0.598606 & & & & \\
\hline & CB3 & 0.623154 & 0.645715 & & & & \\
\hline & CB4 & 0.601572 & 0.623696 & & & & \\
\hline & CB5 & 0.6883 & 0.701976 & & & & \\
\hline & CB6 & 0.663574 & 0.684428 & & & & \\
\hline & CB7 & 0.633675 & 0.646466 & & & & \\
\hline & CB8 & 0.664412 & 0.660401 & & & & \\
\hline & CB9 & 0.652451 & 0.639491 & & & & \\
\hline \multirow{10}{*}{$\begin{array}{l}\text { Employee } \\
\text { Performance }\end{array}$} & EMPER1 & 0.635176 & 0.63833 & 0.4358 & 0.88527 & 0.431257 & 0.855978 \\
\hline & EMPER10 & 0.637747 & 0.640971 & & & & \\
\hline & EMPER2 & 0.689156 & 0.69178 & & & & \\
\hline & EMPER3 & 0.694673 & 0.694464 & & & & \\
\hline & EMPER4 & 0.657561 & 0.652527 & & & & \\
\hline & EMPER5 & 0.66745 & 0.661422 & & & & \\
\hline & EMPER6 & 0.653476 & 0.651074 & & & & \\
\hline & EMPER7 & 0.635255 & 0.633495 & & & & \\
\hline & EMPER8 & 0.682359 & 0.684585 & & & & \\
\hline & EMPER9 & 0.645637 & 0.649397 & & & & \\
\hline \multirow{10}{*}{$\begin{array}{l}\text { Training and } \\
\text { Development }\end{array}$} & TD10 & 0.660556 & 0.722774 & 0.5244 & 0.868552 & & 0.81842 \\
\hline & TD2 & 0.735129 & 0.69876 & & & & \\
\hline & TD3 & 0.499285 & Item Deleted & & & & \\
\hline & TD4 & 0.419422 & Item Deleted & & & & \\
\hline & TD5 & 0.38472 & Item Deleted & & & & \\
\hline & TD6 & 0.355994 & Item Deleted & & & & \\
\hline & TD7 & 0.681244 & 0.717348 & & & & \\
\hline & TD8 & 0.709618 & 0.76847 & & & & \\
\hline & TD9 & 0.670513 & 0.741512 & & & & \\
\hline & TD1 & 0.712217 & 0.693385 & & & & \\
\hline \multirow{11}{*}{$\begin{array}{l}\text { Work } \\
\text { Engagement }\end{array}$} & WE1 & 0.527244 & 0.656849 & 0.36896 & 0.838937 & & 0.786508 \\
\hline & WE10 & 0.619816 & 0.559342 & & & & \\
\hline & WE11 & 0.525634 & Item Deleted & & & & \\
\hline & WE2 & 0.462791 & Item Deleted & & & & \\
\hline & WE3 & 0.614881 & 0.554771 & & & & \\
\hline & WE4 & 0.671731 & 0.679288 & & & & \\
\hline & WE5 & 0.663231 & 0.685117 & & & & \\
\hline & WE6 & 0.603978 & 0.626742 & & & & \\
\hline & WE7 & 0.471869 & 0.503677 & & & & \\
\hline & WE8 & 0.49895 & 0.547328 & & & & \\
\hline & WE9 & 0.568657 & 0.625849 & & & & \\
\hline
\end{tabular}


Discriminant Validity: Discriminant validity is the point to which a level does not associate with contradictory constructs from which it is hypothetical to be at variance (Malhorta, 2004). Fornell and Larcker (1981) suggested that the square root of AVE in each latent variable can be applied to form discriminant validity if this value is more than other correlation values between the latent variables. To do this, a Table was formed in which the square root of AVE was manually calculated and written in bold on the diagonal of Table 3.

Table 3: Discriminant Validity

\begin{tabular}{|c|c|c|c|c|}
\hline & $\begin{array}{l}\text { Compensation and } \\
\text { Benefits }\end{array}$ & $\begin{array}{l}\text { Employee } \\
\text { Performance }\end{array}$ & $\begin{array}{l}\text { Training and } \\
\text { Development }\end{array}$ & $\begin{array}{l}\text { Work } \\
\text { Engagement }\end{array}$ \\
\hline $\begin{array}{l}\text { Compensation and } \\
\text { Benefits }\end{array}$ & 0.636719719 & & & \\
\hline $\begin{array}{l}\text { Employee } \\
\text { Performance }\end{array}$ & 0.593445 & 0.660152255 & & \\
\hline $\begin{array}{l}\text { Training and } \\
\text { Development }\end{array}$ & 0.43476 & 0.495875 & 0.724157441 & \\
\hline Work Engagement & 0.519532 & 0.427142 & 0.353811 & 0.6074216 \\
\hline
\end{tabular}

Hypothesis Testing: In this paper both the direct relationships and moderating relationships incorporated in this study. As PLS-SEM is considered as a soft modelling approach was employed as a finalized model after resolving the reliability and validity assumptions as shown in the section above (please refer to Table 3 for more details). Moreover, the graphical demonstration of the structural model is shown in figure 1.

Figure 2: Structural Model

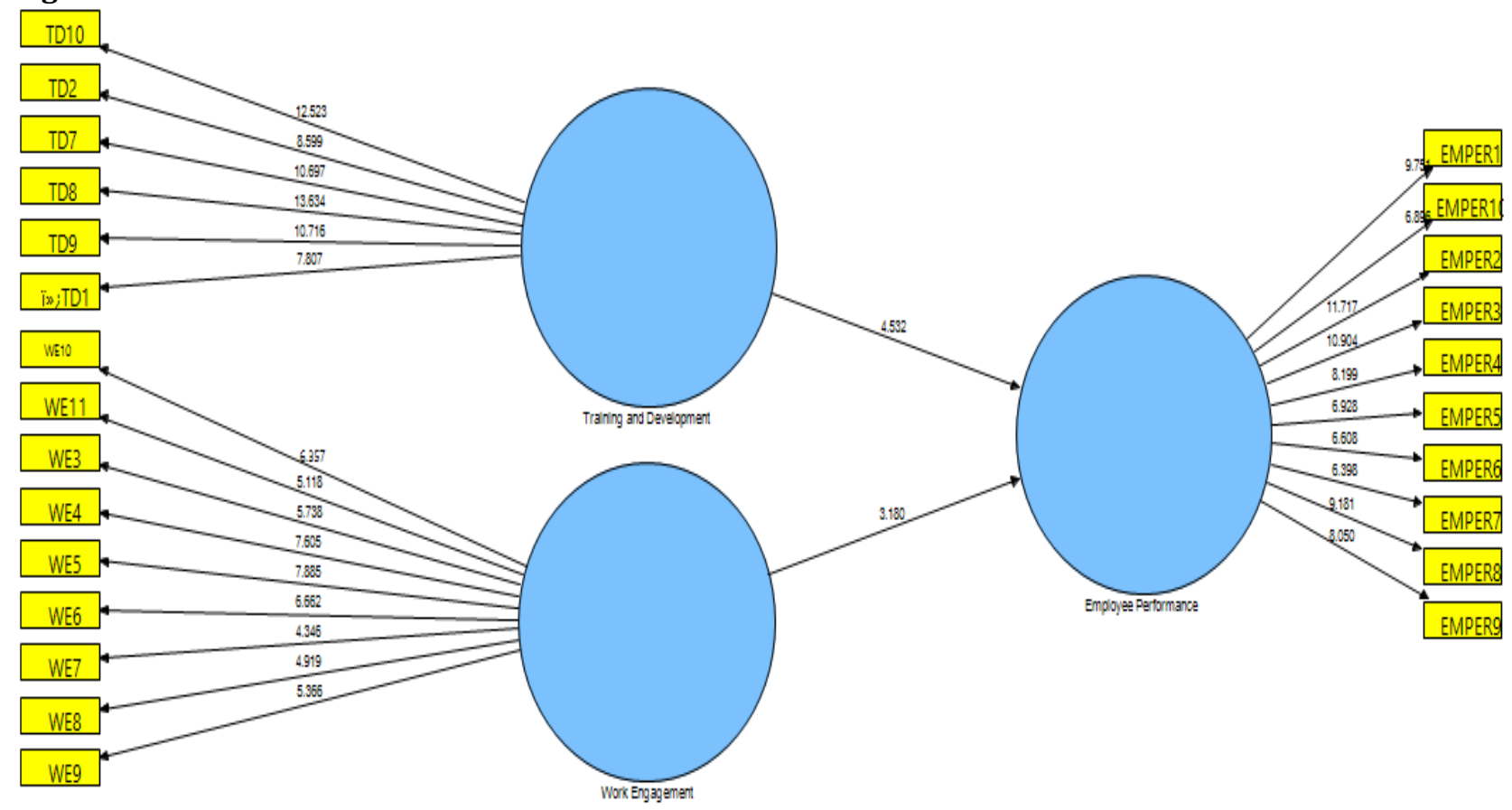

Table 4: Hypothesis Testing

\begin{tabular}{|c|c|c|c|c|c|c|c|}
\hline Hypothesis & Relationships & $\begin{array}{l}\text { Original } \\
\text { Sample } \\
\text { (0) }\end{array}$ & $\begin{array}{l}\text { Sample } \\
\text { Mean } \\
\text { (M) }\end{array}$ & $\begin{array}{l}\text { Standard } \\
\text { Deviation } \\
\text { (STDEV) }\end{array}$ & P-Value & $\begin{array}{l}\mathbf{T} \\
\text { Statistics }\end{array}$ & $\begin{array}{l}\text { Acceptance } \\
\text { / Rejection }\end{array}$ \\
\hline 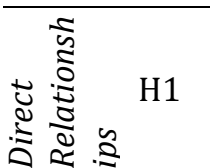 & $\begin{array}{l}\text { Training and } \\
\text { Development } \\
\rightarrow \\
\text { Employee }\end{array}$ & 0.401331 & 0.416636 & 0.088553 & 0.048553 & 4.532107 & Accepted \\
\hline
\end{tabular}




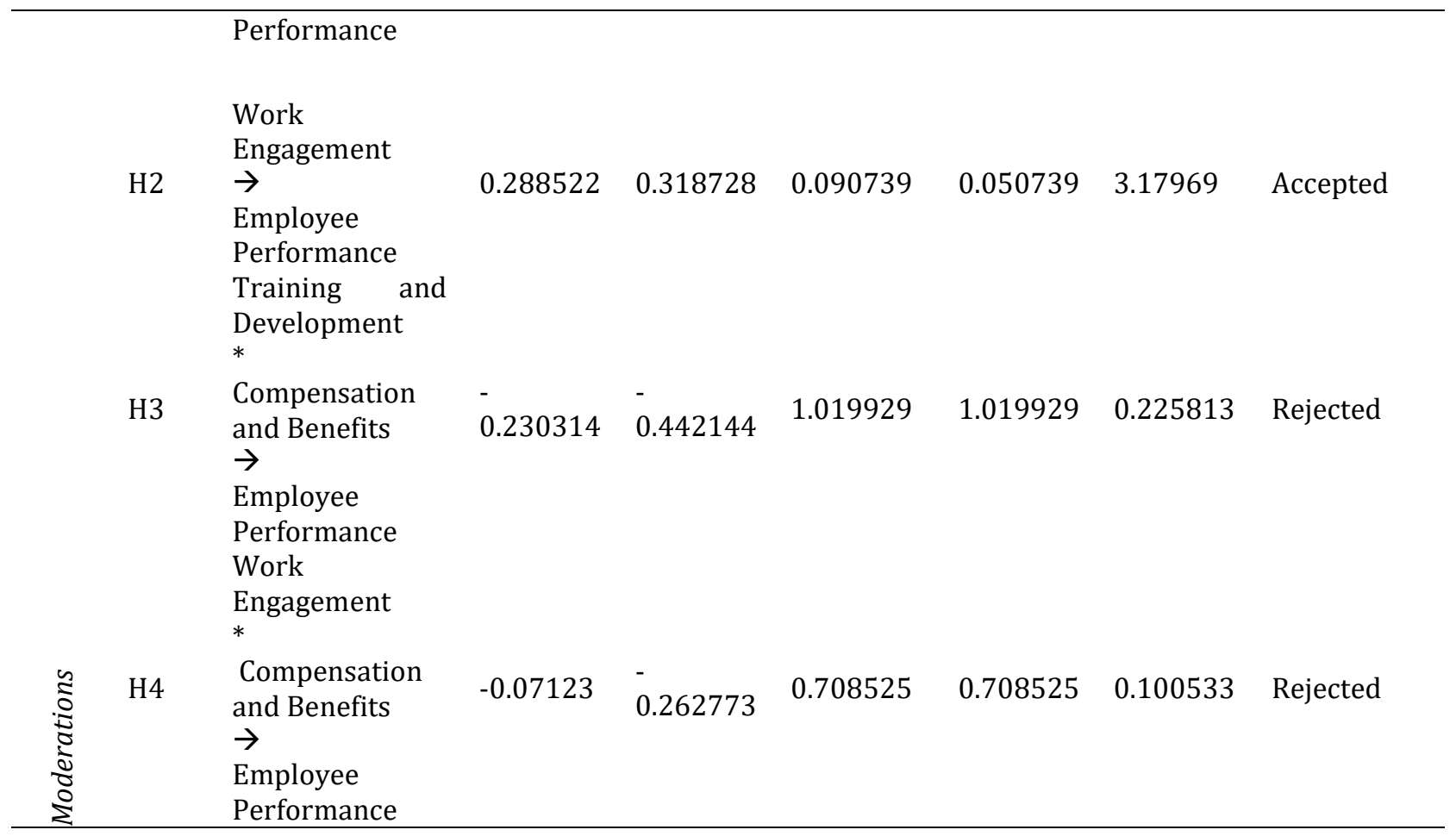

H1: There is a significant relationship between training \& development and employee performance. In the proposition between training and development and employee performance, the $\mathrm{p}$-value and $\mathrm{t}$-statistics were above than the required level of it significance $(P=0.048553$, T-Statistics $=4.532107)$. Therefore the hypothesis between these variables is accepted. Because the T-value is greater than 1.96 and P-value is less than 0.05. Similarly, Sabir et al. (2014) and Franklin et al. (2014) also found a significant influence of training \& development on employee performance.

H2: There is a significant between the relationship work engagement and employee performance. In the proposition between work-engagement and employee performance, the $\mathrm{p}$-value and t-statistics were above than the required level of its significance, $(\mathrm{P}=0.050739$, T-Statistics $=3.17969)$, therefore the hypothesis between these variables is accepted. Similar finding was found by, Saks, $(2019$ found that employees ability diversity is the key job characteristic that influences job engagement.

H3: There is a moderating effect of compensation \& benefits between training \& development and employee performance. The T-Statistics $(0.225813)$ and P-Value (1.019929) have shown that there is no significant moderation of compensation \& benefits between training \& development and employee performance. Therefore the hypothesis for moderation is rejected.

H4: There is a moderating effect of compensation \& benefits between work engagements and employee performance. Similarly, the T-Statistics $(0.100533)$ and P-Value $(0.708525)$ have shown that there is no significant moderation of compensation \& benefits between employee work engagements and employee performance. Therefore the hypothesis for moderation is rejected.

Discussion: This survey has noticed that there a huge impact on HR practice's particularly training \& development and work engagement on employee motivation leading to their productivity and performance. However, this study has found that compensation and benefits does not moderate this might be due to these set of employees have fixed compensation gage which might not helpful in performing more. 
Figure 3: Moderation of Compensation and Benefits between Training \& Development; Work Engagement and Employee Performance

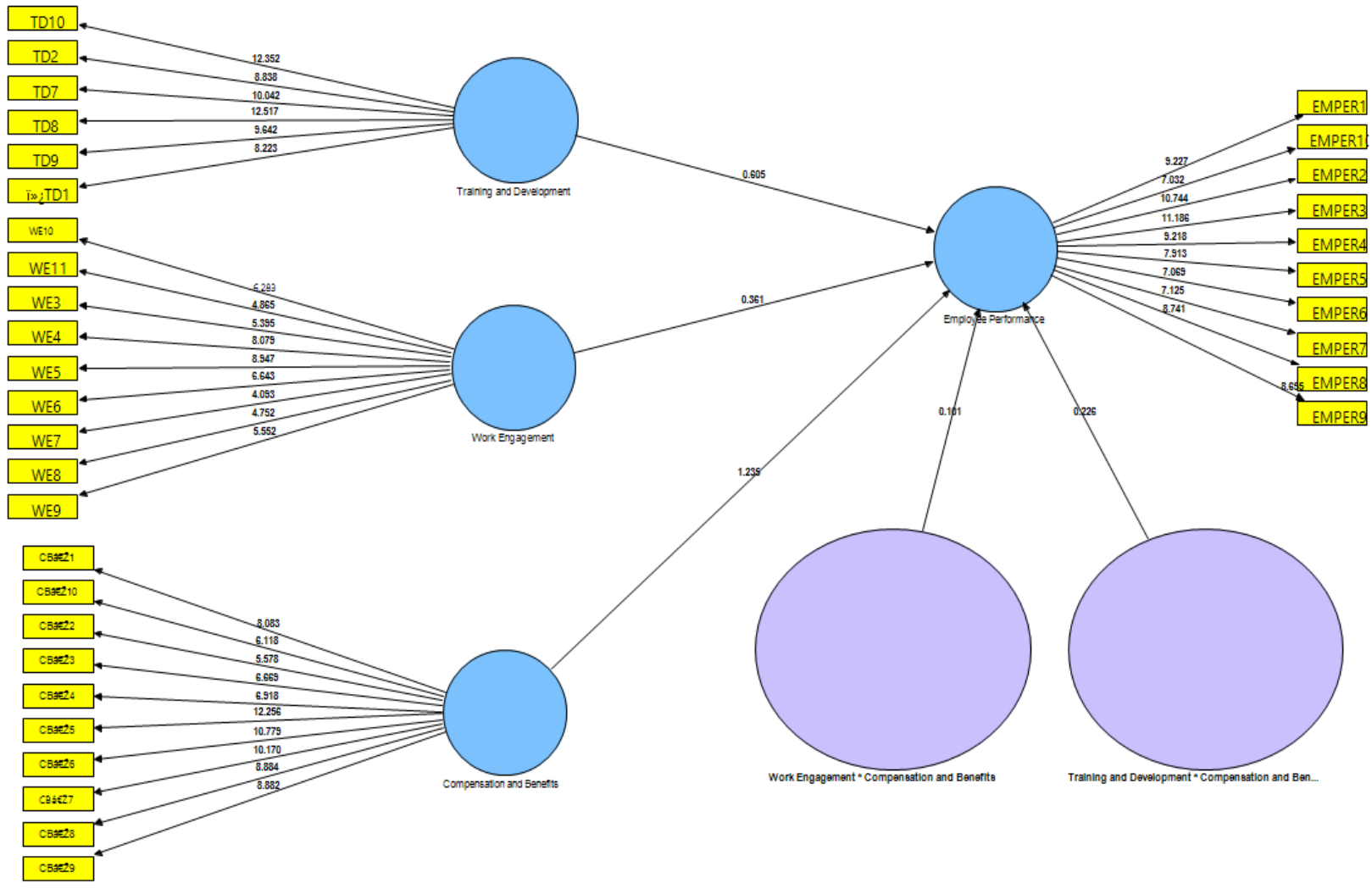

\section{Conclusion}

Insufficiency of training \& development and employee work engagement might result from a number of factors, among which high turnover, employee dissatisfaction, employee miss-commitment, and bad reputation of the employer are perhaps the most obvious ones. Employers in Pakistan have a lower tendency to realize the employee's care and development. In various developing countries, such difficulties are further characteristic of the employment state of affairs, and therefore more important for employment policies, which needed great attention and amendments. This is because the economic situation is quite hard-hitting and employee \& employer both have high work pressure to meet their targets. This study has attempted to add value to knowledge by pondering the employee's training \& development, work engagement, compensation and benefits attributes influencing employee performance. The study found that employee training and work engagements were better predictors of employee performance. However, compensation was found to have no moderating influence on employee performance.

Recommendations: On the basis of the above conclusion the following recommendations were suggested:

- Public institutes in Pakistan should conduct training and development program on a continuous basis since this is the main factor that influences teacher's job performance.

- Training should be premeditated on the basis of institutions specific needs and objectives.

- There is a need to conduct similar studies further elaborating employee and employer problems with different work setting.

- There is further needed to understand why compensation and benefits where found be an insignificant moderator in Public institutes settings.

- In addition, this paper also recommends researchers to conduct a similar study with more sample size and statistical techniques to understand the phenomenon. 
- It is proposed to improve the workplace environment in public institutes so that the teachers have better work engagement.

\section{References}

Abdullah, H. (2009). Major Challenges to the Effective Management of Human Resource Training and Development Activities. The Journal of International Social Research, 2, 11-21.

Abraham, S. (2012). Job satisfaction as an antecedent to employee engagement, SIES Journal of Management, $8(2), 27-36$.

Alan, M. \& Saks (2019). Antecedents and consequences of employee engagement revisited, Journal of Organizational Effectiveness: People and Performance, 6(1), 19-38.

Anitha, J. (2014). Determinants of employee engagement and their impact on employee performance. International Journal of Productivity and Performance Management, 63(3), 308-323.

Copeley, L. (2015). Applicability of Works' Compensation Acts to Mental Disabilities: The Plaintiffs Perspective.

Cunningham, G. B. \& Mahoney, K. (2004). Self-efficacy of part-time employees in university athletics: The influence of organizational commitment, valence of training, and training motivation. Journal of Sport Management, 18, 59-73.

Deepa, E., Palaniswamy, R. \& Kuppusamy, S. (2014). Effect of performance appraisal system in organizational commitment, job satisfaction and productivity. Journal of Contemporary Management Research, 8(1), 72.

Diamantidis, A. D. \& Chatzoglou, P. (2019). Factors affecting employee performance: an empirical approach. International Journal of Productivity and Performance Management, 68(1), 171-193.

Farooq, M. S. \& Kai, Y. T. (2017). Female Teacher Problems at Primary Level in Pakistan Administered Kashmir. International Online Journal of Primary Education, 6(1), 19-25.

Feraro-Banta, L. \& Shaikh, S. (2017). Relation of Compensation and Benefits on Employees' Performance: A Study of Audit Firms in Bahrain. International Advanced Research Journal in Science, Engineering and Technology, 4(5), 175-183.

Fornell, C. \& Larcker D. F. (1981). Evaluating structural equation models with unobservable variables and measurement error. Journal of Marketing Research, 18(1), 39-50.

Hair, J. F., Black, W. C., Babin, B. J., Anderson, R. E. \& Tatham, R. L. (2006). Multivariate Data Analysis: International Edition, 6th ed., Pearson Prentice-Hall, New Jersey.

Hashami, M. F. (2016). The Main Problems of the Students at Primary Level in rural area of Tehsil: Ferozwala, District: Sheikhupura-Pakistan. International Journal of Education (IJE), 4(1), 1-11.

Franklin, D. K., Cowden, R. \& Karodia, M. A. (2014). The Impact of Training and Development on Employee Performance: A Case Study of Escon Consulting. Singaporean Journal of Business Economics and Management Studies, 3(3), 72-105.

Kenney, H. (1992). Management Made Easy, 1st ed. South Carolina: Omron Publishers

Malhorta, N. K. (Eds) (2004). Marketing Research: An Applied Orientation, Pearson Prentice-Hall, Upper Saddle River.

McMillan, H. J. \& Schumacher, S. (2006). Research in Education: Evidence-Based Inquiry. Pearson Education Inc.

Moncarz, E., Zhao, J. \& Kay, C. (2009). An exploratory study of US lodging properties organizational practices on employee turnover and retention. International Journal of Contemporary Hospitality Management, 21(4), 437- 458.

Nabi, M. N., Syduzzaman, M. \& Munir, M. S. (2016). The Impact of Human Resource Management Practices on Job Performances: A Case Study of Dhaka Bank Pvt. Ltd., Bangladesh. Human Resource Management Research, 6(2), 45-54.

Naris, S. N. \& Ukpere, W. I. (2012). Evaluation of human resource development and training at a higher educational institution in Namibia. African Journal of Business Management, 6(49), 118-159.

Nassazi, A. (2013). Effects of Training on Employee Performance: Evidence from Uganda. Business Economics and Tourism. University of Applied Sciences. 
Pakistan Education Statistics Report. (2015-16). National Education Management Information System Academy of Educational Planning and Management Ministry of Federal Education and Professional Training Government of Pakistan - February 2017.

Sabir, R. I., Javed, S., Ahmad, W., Noor, N. \& Munir, H. M. (2014). Assessing Customer Satisfaction Level of Transport Services Using SERVQUAL: A Case OF Daewoo Express, Pakistan. Journal of Basic Applied Science Research, 4(2), 207-213.

Shariful Alam, M., Shahrani, A. S, Sahabuddin, M. \& Akter, S. (2013). Relationship between Employee Recognition and Employee Contribution in Service Industry. International Journal of Business and Marketing Management, 1(1), 1-8.

Shem, J. M. \& Ngussa, B. M. (2015). Effect of Training on Employees' Performance: A Case of Institutions of Higher Learning in Arusha City, Tanzania. International Journal of Science and Research, 6(10), 19241930.

Sultana, A., Irum, S. Ahmed, K. \& Mehmood, N. (2012). Impact of Training on Employee Performance: A Study of Telecommunication Sector in Pakistan, Interdisciplinary Journal of Contemporary Research in Business, 4(6), 646-661.

Van Dorsal, W. R. (1962). The successful supervisor. New York: Harper and Row.

Zack, M., James, M. and Satyendra. S, (2009). Knowledge Management and Organizational Performance: An explanatory Analysis. 